\title{
Mendukung Bangkitnya Kesehatan dan Sains Bangsa Indonesia Menuju Era Global
}

\author{
Titik Respati \\ Bagian Ilmu Kesehatan Masyarakat, Fakultas Kedokteran, Universitas Islam Bandung, Bandung
}

Sebuah perjalanan yang cukup panjang telah ditempuh oleh jurnal Global Medical and Health Communication (GMHC) yang berawal di tahun 2012 untuk memberikan ruang bagi para peneliti, dosen, dan pemerhati masalah kesehatan dalam menyampaikan hasil penelitian maupun ide dan metode terbarunya. Jurnal yang berkualitas menjadi salah satu dukungan untuk memastikan transfer pengetahuan melalui penyebarluasan hasil penelitian untuk dapat dimanfaatkan secara baik.

Jurnal GMHC yang diterbitkan oleh Fakultas Kedokteran, Universitas Islam Bandung (Unisba) telah terakreditasi Direktorat Jenderal Penguatan Riset dan Pengembangan, Kementerian Riset, Teknologi, dan Pendidikan Tinggi Republik Indonesia dengan Nomor 2/E/KPT/2015 tanggal 1 Desember 2015. Selain itu, jurnal ini telah terdaftar pula dalam Directory of Open Access Journals (DOAJ) tanggal 9 Mei 2017. Dengan telah terindeks dalam DOAJ maka jurnal GMHC dapat menjangkau pembaca yang lebih luas tidak saja di dalam negeri, tetapi juga di luar negeri. Keberhasilan ini tidak lepas dari kerja keras para pengurus terutama para mitra bestari dan dewan redaksi yang dipimpin oleh Prof. Herry Garna, dr., Sp.A(K), Ph.D.

Pencapaian ini telah mendapatkan respons positif dari para peneliti dan pemerhati masalah kesehatan terutama di Indonesia serta terbukti dengan semakin banyak artikel yang dikirimkan. Dibanding dengan awal pendiriannya pada tahun 2012 sampai tahun 2017 ini jumlah artikel yang dikirimkan menjadi 3 (tiga) kali lipat banyaknya. Artikel yang telah diterima oleh jurnal GMHC menunjukkan peningkatan kualitas artikel baik dari metodologi maupun penulisannya sehingga diharapkanakansangatbermanfaatbagipembaca. Informasi yang diperoleh dari hasil penelitian sebaiknya segera tersampaikan sehingga dapat dimanfaatkan secara cepat. Sebagai dukungan penyebaran informasi terutama hasil penelitian maka penerbitan GMHC yang sejak tahun 2013 cukup 6 bulan dalam setahun pada tahun 2017 menjadi setiap 4 bulan dalam setahun.

Setelah menjadi jurnal terakreditasi nasional, jurnal GMHC berupaya mempersiapkan diri agar dapat lebih berperan di arena global. Dalam pentas global, saat ini nama Indonesia belum banyak dikenal. Menurut Richard Horton dalam The Lancet bahwa Indonesia memiliki potensi yang luar biasa dari berbagai segi baik dari segi kekayaan alam maupun dari ke-bhinneka-annya di bidang kebudayaan, bahasa, dan aspek lainnya. Dengan moto Bhinneka Tunggal Ika-nya Horton menyatakan:

"Indonesia's message is that unity must always overcome the diversity that threatens to tear us apart. Indonesia's values, its predicaments, and its attempted solutions have enormous global bearing."

Masalah kesehatan di Indonesia tidak saja berhubungan dengan penyakit menular maupun tidak menular, tetapi juga berhubungan langsung dengan persoalan pelayanan kesehatan, akses, pembiayaan, kondisi lingkungan baik lingkungan lokal, nasional, maupun global. Tantangan untuk para peneliti dan pemerhati masalah kesehatan adalah bagaimana menjawab masalah tersebut. Suara dari bidang sains dan kesehatan mengenai persoalan dan juga tantangan di Indonesia masih sangat senyap sehingga jurnal GMHC bertekad dengan dukungan para penulis, pembaca, dan pemerhati berupaya mulai menjadi sarana bagi bangsa Indonesia agar dapat berkiprah di tingkat dunia terutama dalam bidang kesehatan.

Korespondensi: Dr. Titik Respati, drg., MSc.PH. Bagian Ilmu Kesehatan Masyarakat, Fakultas Kedokteran, Universitas Islam Bandung. Jln. Tamansari No. 22, Bandung, Jawa Barat, Indonesia. E-mail: respatitik@yahoo.com 


\section{Supporting the Rise of Health and Science for Indonesian People to Prepare for the Global Era}

Global Medical and Health Communication (GMHC), which started in 2012, is developed to ensure there is room for researchers, lectures and other health practitioners to communicate either their research findings, newest methods or their ideas to others. A quality journal is one of the best ways to support the transfer of knowledge among them that can be used for good cause.

In not so long time, GMHC journal published by Faculty of Medicine, Universitas Islam Bandung have already accredited by Ministry of Research, Technology and Higher Education of the Republic of Indonesia Number 2/E/KPT/2015 since $1^{\text {st }}$ December 2015. It's also indexed in Directory of Open Access Journals (DOAJ) on $9^{\text {th }}$ May 2017. With DOAJ indexing this journal are able to reach international audiences. Those are achieved through hard work of editorial team lead by Prof. Herry Garna, dr., Sp.A(K), Ph.D.

This achievement received positive responses from researchers, lecturers and health observers alike showed by articles submitted which are triple compare to the number of articles received in its early time. The quality of the articles also show improvement both in methodology and written that will be beneficial for audiences. Research findings were best to disseminate as early as possible so they can be used properly. To support these GMHC publication which was every six months in a year will publish every four months in one year starting from 2017.

After accredited as National Journal, GMHC prepared to be involved in the global arena. In international arena, Indonesia is still not widely known. As Richard Norton stated in The Lancet that Indonesia has huge potential not only in natural resources but also because of its diversity in language, culture and other aspects. With Bhinneka Tunggal Ika he said that:

"Indonesia's message is that unity must always overcome the diversity that threatens to tear us apart. Indonesia's values, its predicaments, and its attempted solutions have enormous global bearing."

The challenges on the health of Indonesian people are not only for communicable and noncommunicable disease but also on health services, access, health financing and the environment either local, national or global. Researcher and other interest parties need to find ways on how to address those issues. The news from science and health about challenges and opportunities in Indonesia is still very quiet that GMHC hopes to become the best means to support researchers, lecturers, and health practitioners to become the voice of Indonesia, especially in health.

\section{Daftar Pustaka}

1. Elsevier. Scopus content coverage guide. Update January 2016 [diunduh 31 Juli 2017]. Tersedia dari: https://www.elsevier.com/ data/assets/pdf_file/ooo7/69451/scopus_ content_coverage_guide.pdf.

2. Hamid ARAH. The voice of Indonesian health scientists. MJI. 2017;26(1):1-2.

3. Horton R. Offline: Indonesia-unravelling the mystery of a nation. Lancet. 2016;387(1021): 830.

4. Respati T, Sufrie A. Socio cultural factors in the treatment of pulmonary tuberculosis: a case of Pare-Pare municipality South Sulawesi. GMHC. 2014;2(2):60-5.

5. Respati T, Ibnusantosa G, Rachmawati M. Knowledge about byssinosis and the use of face-masks. GMHC. 2013;1(1):3-8.

6. Respati T, Nurhayati E, Mahmudah, Feriandi Y, Budiman, Yulianto FA, Sakinah K. Pemanfaatan kalender 4M sebagai alat bantu meningkatkan peran serta masyarakat dalam pemberantasan dan pencegahan demam berdarah. GMHC. 2016;4(2):121-8. 